\title{
Cultivation Path of Craftsmanship Spirit for Transformation and Upgrading Process in Manufacturing Industry
}

\author{
Lei Zhong, Qian Rong \\ School of Marxism \\ Wuhan University of Science and Technology \\ Wuhan 430070, China
}

\begin{abstract}
Manufacturing industry has become an important criterion for measuring a country's overall national strength and international competitiveness. However, in the current view, China is a manufacturer of quantity rather than a manufacturer of quality. In order to change this situation, it is necessary to promote the transformation and upgrading of the manufacturing industry. As a professional spirit, the craftsmanship spirit is the spiritual guarantee to improve quality and efficiency and promote the transformation and upgrading of the manufacturing industry. This work took the practical dilemma of cultivating craftsmanship spirit in universities and enterprises as a breakthrough, actively explored the realistic path of cultivating craftsmanship spirit from perspectives of government, enterprises and universities, and provided intellectual support for the transformation and upgrading of the manufacturing industry.
\end{abstract}

Keywords-Manufacturing industry; Craftsmanship spirit; Transformation and upgrading; Innovation

\section{INTRODUCTION}

Since China is increasingly approaching the center of the world, the opportunities for development are increasing while the challenges are becoming more intense. If China wants to enhance its competitiveness and realize the transformation and upgrading of the manufacturing industry, it should carry forward the craftsmanship spirit and create good social customs while vigorously implementing the strategy of innovationdriven development and intensifying the cultivation of highquality talents, so as to inject spiritual vitality into the economic development of China.

\section{ConNOtATION AND Time VAluEs OF THE CRAFTSMANSHIP SPIRIT}

There is currently no authoritative definition of the craftsmanship spirit in academics. However, throughout the vast number of scholars at home and abroad on the interpretation of the craftsmanship spirit, it is not difficult to find that there are two commonalities, which exist in the field of thought and behavior. In the field of thought, ideas of devotion, selfless dedication and enthusiasm are often collectively referred to as the craftsmanship spirit. In the field of behavior, perseverance, excellence and innovation are often collectively referred to as craftsmanship spirit. Craftsmanship spirit is a professional spirit, belonging to the category of ideology. It is the expression of the value orientation and behavior habits of practitioners, which has the distinctive appearances of dedication, innovation and devotion.

\section{A. Craftsmanship spirit is the spiritual guarantee for the development of manufacturing industry}

With the accelerating process of economic globalization, the manufacturing industry has been hit hard, and it urgently needs transformation and upgrading. Therefore, some countries have issued relevant policies to adjust. It is undeniable that due to the support of solid industrial-strength, some developed countries, such as the United States and Germany, have rapidly adjusted their manufacturing development plans to enhance their international competitiveness in accordance with the laws of economic development. If China wants to improve its competitiveness and increase its market share in the increasingly fierce international market, it needs to improve its innovation ability in product production and promote the transformation and upgrading of the manufacturing industry.

Nowadays, in order to pay attention to the development of the real economy and actively promote the transformation and upgrading process of the manufacturing industry, it is necessary to cultivate and promote craftsmanship spirit, improve quality of the industrial main body, and create an industry atmosphere of excellence. With the comprehensive deepening reform, craftsmanship spirit is enriching new connotation nowadays: firm, practical and striving for excellence. If the manufacturing industry wants to create such a state, it is obviously not enough to rely on rigid slogans. It is necessary to use craftsmanship spirit as the soul to mobilize senior technical personnel in the industry, strengthen ideological education, encourage them to play an exemplary role, and lead staff of various departments to enhance their sense of dedication and craftsmanship spirit.

\section{B. Craftsmanship spirit is a powerful driving force to realize life value}

From ancient times to the present, when thinking of the craftsmanship inheritance, the first thing that comes to mind is the learning scene where mentor teaches and apprentice concentrates on learning. In this process, the core requirement of the mentor is "professional excellence and moral integrity", 
which is actually the most essential expression of the craftsmanship spirit. If technical talents want to achieve selfworth, they should not only have superb skills, but also noble virtue as support. The craftsmanship spirit is here cleverly expressed through the word "professional excellence and moral integrity".

For technical personnel with craftsmanship spirit, they regard the labor process as a manifestation of their own lives and regard labor products as the crystallization of their lives. They have independent control in the labor process and construct products according to self-understanding. In this process, self-will is quietly infiltrated into the results, so that self-worth is also perfectly presented through their works. Cultivating and promoting craftsmanship spirit can not only support individuals to overcome difficulties and bring forth new ideas, but also enhance competitiveness and broaden career paths. Examples shown in "Great Craftsmen Build Dreams with Ingenuity" indicate that only those who love their jobs, preserve, strive for excellence and have the courage to innovate can face difficulties bravely, concentrate on their work, break through difficulties and realize self-value while making contributions to the country.

\section{Craftsmanship spirit is the urgent demand for the formation of social customs}

The current manufacturing industry pattern is facing major adjustments. China proposed to implement the "Made in China 2025" plan in Report on the Work of the Government 2015, which adheres to innovation-driven, intelligent transformation, foundation reinforcement and green development and accelerates the transition from a manufacturer of quantity to a manufacture of quality [1]. The key to achieving this goal is to improve the quality of Chinese manufacturing, which is precisely the biggest dilemma faced by China's manufacturing industry. For more than 40 years of reform and opening up, China's manufacturing has spread all over the world, occupying an absolute market share. However, in terms of product quality, process and design, there is still a big gap to become a manufacture of quality [2]. The value of putting profits first still exists in a certain range, and fake products are still full of our daily life, therefore, the international recognition of Chinese manufacturing is generally not high.

The craftsmanship spirit should not only be possessed by manufacturers, but also by technical personnel of all walks of life. The craftsmanship spirit should not only exist in the enterprise, but also in society. Workers from all walks of life should establish ideals and beliefs of dedication and excellence, get rid of the stale and bring forth the fresh, have courage to innovate, create excellent services and products diligently, create an active social atmosphere and form a good social custom, so as to promote the "Made in China 2025" strategy to be successfully implemented.

\section{REASONS FOR THE LACK OF CRAFTSMANSHIP SPIRIT IN MANUFACTURING INDUSTRY}

The manufacturing industry is in a critical position in the development of the country's real economy and it is one of the standards to measure strong modernization country. The development level of the manufacturing industry not only affects the lifeline of the national economy, but also plays a decisive role in the national living standards. From the perspective of the important position to cultivate the craftsmanship spirit, universities and enterprises have their own limitations.

\section{A. There are loopholes in the cultivation model of craftsmanship spirit in universities}

Universities are the important place to cultivate craftsmanship spirit, and classroom is an important field for cultivating craftsmanship spirit [3]. At present, most universities carry out ideological education through curriculum arrangement, but there are inevitably some loopholes in this form. First, the teaching method is relatively simple. At present, universities mainly carry out ideological education through theoretical explanations. The teaching process is inevitably boring, leading students to only take notes and take photos of teacher's courseware in the process of studying, therefore, the group participation is generally low. In this way, the inheritance effect of craftsmanship spirit is greatly discounted. Second, there are fewer relevant teaching materials in textbooks. Teachers in universities mainly rely on ideological and political textbooks to teach, but throughout the current ideological and political textbooks, contents related to the craftsmanship spirit is insufficient. Teachers mainly supplement their teaching through conference documents and practical cases, and there are few relevant model teaching cases that can be used for reference. In this way, it is impossible to let students deeply understand and carry forward the craftsmanship spirit.

\section{B. The ideological awareness of entrepreneurs and workers is generally limited}

As the carrier material of economic benefits output, enterprises are an important base for carrying forward craftsmanship spirit and creating a spirit of excellence and dedication. However, due to the nature of entrepreneurs and the limited ideological awareness of workers, the promotion of craftsmanship spirit is not effective. First, from the perspective of entrepreneurs, their purpose of starting a business is mainly to make profits. Quickly occupying the market in a fiercely competitive economic environment and seizing the largest share of the market to maximize profits are their primary goals. Their values of pursuing rapid profitability, speed and profits make it impossible to craft products, production methods and management models, so that the craftsmanship spirit is difficult to form in the enterprise. Second, from the perspective of grassroots workers, their level of education is limited and ideological awareness is not high. Most of them think that "promotion and wealth" is a display of self-worth and selfstatus. It is precise because of this ideological limitation that they put "drilling technology" and "growth and progress" in opposition, and they no longer do their best for work, instead, they try their best to study how to get rid of the grassroots and quickly enter the agency office. This awareness limitation also hinders the formation of craftsmanship spirit from top to bottom. 


\section{CUlTiVATION PATH OF CRAFTSMANSHIP SPIRIT IN THE MANUFACTURING INDUSTRY}

At present, although China is already the second largest economy in the world, the level of economic development is still in a big but not strong situation, and manufacturing industry is in urgent need of transformation and upgrading. To comprehensively improve the quality and level of China's manufacturing industry and to promote the cultivation of craftsmanship spirit, it is necessary to combine government position, enterprise brand building and university personnel training.

\section{A. The government should strengthen guidance}

The Report of the 19th National Congress of the Communist Party of China emphasizes that in deepening the structural reform of the supply side, it is necessary to "build a knowledge-based, skilled and innovative labor force to promote the spirit of model workers and craftsmanship spirit, and create a glorious social custom of working and a professional spirit of excellence" [4]. It is necessary to give play to the role of human capital and pay more attention to mobilizing and protecting people's enthusiasm [5]. People is the most active factor in productivity, and two types of people are the most critical in improving the quality of supply, the entrepreneurs who dare to adventure and the craftsmen who strive for excellence. In order to accelerate the "skilled province strategic project" with the main goal of "innovationdriven development capability", first, the government and social self-governing organizations (industry associations) should formulate appropriate development strategies for enterprises to ensure the vitality of enterprise development. Second, entrepreneurs are the helm of enterprises and control the lifeblood of enterprise development. In order to further enhance the competitiveness of enterprises, the government should create a more relaxed operating space and legal framework for entrepreneurs. Third, education is the most effective way to improve people's ideological and political level. The government should actively construct a skill training system for workers that conforms to the national production system, product quality standards and educational quality standards, and carry forward cultural traditions to make highquality production become a social habit.

\section{B. Focus on brand building}

In the past 20 years of development, most enterprises have been greatly impacted and their performance has gradually declined due to the increasingly fierce international competition. If enterprises want to enhance their vitality and enhance their self-competitiveness, they need to vigorously promote the craftsmanship spirit and provide spiritual motivation for self-development. At the same time, they should be strict with quality and create a unique brand. First, they should establish a production credo of "quality is the guidance". Quality is the primary premise for the creation of enterprise brands. From entrepreneurs to grassroots workers, they should all establish a sense of "product is an honor", link product quality with personal character, and abide by the production credo of "quality is the guidance". Second, they should continuously innovate to form enterprise characteristics.
Entrepreneurship and innovation is not only the source of economic vitality, but also the key to achieving breakthrough development for enterprises and individuals. In order to enhance competitiveness, enterprises need to increase investment in scientific research equipment and personnel training, constantly promote innovation, improve product upgrading, and at the same time perceive consumer psychology, so as to produce products welcomed by consumers. Thus, they can form enterprise characteristics and build an enterprise brand. Third, they should make good use of Internet technology. Internet technology has been spreading quickly like wildfire since it appears, especially in the 21st century, Internet technology has expanded to all walks of life. Enterprises should make rational use of the Internet platform and build a collaborative innovation system with interaction as the core, thus enhancing the brand's influence in the market.

\section{Attach importance to personnel training}

As the main base for education, universities must perform their duties, which should actively promote and cultivate craftsmanship spirit, and build a career-oriented talent training system. First, they should attach importance to the cultivation of students' professional outlook. As a gathering place of ideology and culture, universities are full of complex and changeable social ideological trends, which can strongly impact students' values, thus causing distortion of some students' views on employment. Universities should guide students' professional outlook and increase the cultivation of craftsmanship spirit, so as to ensure that students can establish a correct professional outlook and reduce their employment confusion. Second, they should strengthen cooperation among production, education and research. As the main place to cultivate young people in the new era, universities shoulder the heavy responsibility of transporting talents for society and solving employment pressures. Universities should consciously strengthen cooperation with enterprises and research institutes, take market needs as the relevant teaching orientation, cultivate professional talents, take the initiative to undertake scientific research projects, adhere to put morality first and cultivate high-quality technical talents needed in the first line [6]. Third, they should strengthen the intensity of practical activities. At present, universities mainly adopt curriculum setting to train talents, and teachers mainly adopt theoretical teaching methods, which can reduce students' ability to understand knowledge. Universities should enrich teaching methods, increase practical curriculum setting, and guide students to establish the awareness of craftsmanship spirit while paying attention to the cultivation of professional skills.

\section{SUMMARY}

The craftsmanship spirit is still full of vigor and vitality today when China's economic development has entered a new stage. It is obviously not enough to rely on rigid slogans to cultivate craftsmanship spirit and promote the transformation and upgrading of the manufacturing industry. First of all, the whole industry should thoroughly understand the national development strategy and take the initiative to undertake the responsibility to develop the economy. In addition, it should strengthen cooperation with universities to ensure the quality of 
talent cultivation. Finally, it should fully mobilize the industry's senior technical personnel and encourage them to innovate and create a characteristic brand. The transformation and upgrading of the manufacturing industry can have a strong spiritual guarantee only if the government, enterprises and universities have coordinated to carry forward the craftsmanship spirit.

\section{REFERENCES}

[1] Li Keqiang. Report on the Work of the Government - Delivered at the Third Session of the Twelfth National People's Congress on March 5, 2015[R]. Beijing, 2015.
[2] Wang Guoxiong. The Cultivation Path of Craftsmanship Spirit in Higher Vocational Colleges Under the Vision of China's Intellectual Property[J]. Education and Occupation, 2019 (13) 92 - 96.

[3] Yang Ying. Value Implication, Internalization Pattern and Realization Path of Craftsmanship Spirit of Higher Vocational Students[J]. School Party Building and Ideological Education, 2017 (22) 43 - 44, 49.

[4] Xi Jinping. Secure a Decisive Victory in Building a Moderately Prosperous Society in All Respects and Strive for the Great Success of Socialism with Chinese Characteristics for a New Era[R]. Beijing, 2017.

[5] Wang Xi. Promoting the Construction of Modern Economic System with Supply-side Structural Reform[J]. Journal of Hebei University (Philosophy and Social Sciences), 2018 (3) 92 - 95.

[6] Du Xiaoguang. Cultivation of Craftsmanship Spirit in Higher Vocational Colleges in the New Era[J]. Education and Occupation, 2019 (7) 78 - 83. 